HEAD AND NECK

\title{
The rising incidence of parotid metastases: our experience from four decades of parotid gland surgery
}

\author{
Incremento dell'incidenza di metastasi alla ghiandola parotide: \\ analisi della nostra esperienza in quattro decenni di chirurgia parotidea
}

\author{
A. FRANZEN ${ }^{1}$, A. BUCHALI ${ }^{2}$, A. LIEDER 1 \\ 1 Department of Otorhinolaryngology, ${ }^{2}$ Department of Radio-Oncology and Radiotherapy, Head and Neck Surgery, \\ Brandenburg Medical University-Theodor Fontane, Neuruppin, Germany
}

\begin{abstract}
SUMMARY
Secondary neoplasia in the parotid gland is increasingly frequent. We examined outcomes from 40 years of parotid surgery to analyse patterns for metastasis, review the staging procedure and discuss management. We retrospectively examined 772 consecutive cases of parotid surgery in a university hospital between 1975 and 2015 and assessed changes in incidence and management over four decades. In all, 71\% percent of patients were male and $29 \%$ were female, with a mean age of 68 years, aged between 23 and 93 years. We diagnosed 683 parotid tumours of which $15.8 \%(n=108)$ were malignant; $44 \%(n=48)$ of all malignant lesions were metastases. The incidence of malignant tumours rose from $8 \%$ in the first decade, $14 \%$ in the second, $17 \%$ in the third to $21 \%$ in the fourth. The incidence increased even further from $10 \%$ in the first to $57 \%$ in the final decade. Most frequent tumours were metastases of squamous cell carcinoma (79\%), and the majority of these lesions (87\%) arose from above the clavicle, with 30 primary tumours in the skin. In most cases, the skin tumour had been excised between 6 and 24 months prior to parotid metastasis. Management consisted of surgery with neck dissection. 48 patients $(67 \%)$ received adjuvant therapy, but despite aggressive multimodal treatment, disease progressed in the majority of cases, in 57\% squamous cell carcinoma of the skin primaries, $67 \%$ of mucosal primaries above the clavicle and $83 \%$ of infraclavicular primaries. Parotid malignant tumours are increasing in incidence, mostly due to a rise in metastatic malignant tumours within the parotid gland, most of which are metastases of skin tumours, commonly squamous cell carcinoma. Despite multimodal therapy, their recurrence and progression rate remains high. We propose inclusion in head and neck follow-up in all cases of head and neck skin cancers.
\end{abstract}

KEY WORDS: Parotid • Surgery $・$ Neoplasm・Metastases

\section{RIASSUNTO}

La neoplasia secondaria nella ghiandola parotide è un reperto sempre più frequente nella chirurgia parotidea. Vengono qui presentati i nostri risultati in quaranta anni di chirurgia parotidea, analizzando le modalità di metastasi in pazienti con lesioni metastatiche della ghiandola parotide, le procedure operatorie e la gestione dei pazienti. Sono stati esaminati retrospettivamente 772 casi consecutivi di chirurgia parotide in un ospedale universitario tra il 1975 e il 2015 e valutate le variazioni di incidenza e di gestione della patologia nel corso di quattro decenni (I: 1975-1985; II: 1986-1995; III: 1996-2005; IV: 2006-2015). Sono stati diagnosticati complessivamente 683 tumori della parotide, di cui il 15,8\% $(n=108)$ sono rivelati essere di natura maligna; a loro volta, il $44 \%(n=48)$ di tutte le lesioni maligne si sono rivelate essere metastasi. Si è inoltre potuto constatare come, con l'andare del tempo, i tumori maligni della ghiandola parotide abbiano incrementato la loro incidenza con un aumento dall' $8 \%$ nel primo decennio, del $14 \%$ nel secondo, del $17 \%$ nel terzo fino al $21 \%$ nel quarto decennio. L'incidenza di metastasi alla ghiandola parotide è altresì ulteriormente aumentata dal $10 \%$ nella prima decade fino al $57 \%$ nell'ultimo decennio. Il $71 \%$ per cento dei pazienti era di sesso maschile e il $29 \%$ era di sesso femminile, con un'età compresa tra i 23 ei 93 anni (media di 68 anni). La diagnosi istopatologia più frequente era quella di metastasi di carcinoma a cellule squamose (79\%). La grande maggioranza delle lesioni primarie era localizzata in lesioni sopra la clavicola (87\%), delle quali 30 tumori primari erano localizzati nel cuoio capelluto e nella cute del collo. Nella maggior parte di questi casi, il tumore primario è stato rimosso tra 6 e 24 mesi prima della metastasi parotidea e i pazienti sono stato seguiti in modo subottimale. La gestione consisteva in intervento chirurgico di dissezione del collo. 48 pazienti $(67 \%)$ sono stati sottoposti a terapia adiuvante, ma nonostante il trattamento multimodale aggressivo la malattia è progredita nella maggior parte dei casi, nel 57\% dei casi di metastasi da carcinoma a cellule squamose cutaneo, nel 67\% da metastasi di tumore primario della mucosa sopra la clavicola e l'83\% dei casi di metastasi da primitivo infraclaveare. I tumori maligni parotidei registrano un progressivo aumento di incidenza, in gran parte dovuto ad un incremento delle lesioni metastatiche parotidee. I più frequenti tumori primitivi sono melanomi maligni precedentemente asportati, e i carcinomi a cellule squamose del cuoio capelluto e del collo precedentemente operati. Nonostante la terapia multimodale il tasso di recidiva e di progressione rimane alto. $\grave{E}$ auspicabile per $i$ tumori della testa e del collo un programma di follow-up, come già in atto per i tumori della mucosa della testa e del collo.

PAROLE CHIAVE: Parotide $\bullet$ Chirurgia $\bullet$ Neoplasia $\bullet$ Metastasi 


\section{Introduction}

Malignant tumours of the parotid gland are a rare but a varied group of tumours, comprising of at least 24 histological types of malignant lesions of epithelial or mesenchymal origin ${ }^{1}$. The parotid gland hosts metastases, most commonly from tumours of the head and neck region. The highest proportion of parotid metastases have been reported to arise from squamous cell carcinoma of the skin of the scalp, face and neck, but their frequency varies between populations in different geographical locations with different levels of sun exposure ${ }^{2-4}$.

Knowledge about clinical and epidemiological aspects of malignant neoplasms of the parotid gland is scarce compared to carcinomas of the upper aerodigestive tract. This is due to the rarity of such tumours, their variance in histological types and also the fact that salivary gland tumours are often reported without allocation to a particular salivary gland. The majority of reports is based on data collections of clinical centres or institutes for pathology $35-8$. Population-based data or data from tumour data banks are rare ${ }^{19-11}$.

Considering the limitations in which published data can be interpreted, the incidence of a malignant parotid neoplasm is expected to be 1 in 100,000 per year ${ }^{9-11}$. The proportion of primary glandular tumours is thought to be $50-70 \%{ }^{9-11}$, but this depends on geographical location. In Europe and the United States, the proportion of metastatic tumours in parotid malignancies is reported to be around $25 \%{ }^{512}$. In sun-exposed populations with a higher risk of skin malignancies in the Southern Hemisphere, data from Australia report the proportion of metastatic parotid tumours arising from skin malignancies to be significantly higher at $60 \%{ }^{2-4} 1314$. Vice versa, only 1 to $3 \%$ of cutaneous skin malignancies are thought to metastasise into the parotid or periparotid lymph nodes ${ }^{15}$.

While in some patients a primary tumour is diagnosed at the same time as a parotid metastasis ${ }^{5}$, the majority of patients with parotid metastasis will present with the metastasis first and may undergo parotid surgery before their primary tumour is diagnosed and staged.

There are numerous studies, all of them retrospective, which attempt try to identify risk factors for metastasis of cutaneous cancers to the parotid, and how to manage them.

By examining outcomes from our practice of 40 years, we looked for patterns and timing of metastases in patients with metastatic tumours located in the parotid gland. We also critically review the staging process and discuss management and survival of patients presenting with parotid metastases. This has helped us establish our current practice of management followed by clinic follow-up with a schedule of non-invasive imaging.

\section{Materials and methods}

We retrospectively examined 772 consecutive cases of parotid surgery. All procedures were performed by a Consultant Head and Neck Surgeon in a Head and Neck unit at a university teaching hospital between 1975 and 2015. Either total conservative parotidectomy with facial nerve preservation or superficial parotidectomy were performed. Open parotid biopsies were performed in a few selected cases. Neck dissections were performed contemporaneously in selected cases. Postoperative histopathology examination was performed in-house with samples sent to reference laboratories as appropriate. All patient data were obtained by hand searching of patient records and analysed using a statistical software package (Apache Open Office Calc with R Statistics Package).

\section{Ethics considerations}

All investigations and treatments are established clinical practice and were carried out according to accepted practice and in compliance with medical principles of the Declaration of Helsinki and German Federal Law. Informed consent was obtained from all patients prior to treatment. In this retrospective case series, formal ethics approval was not required.

\section{Results}

In 772 consecutive parotid surgeries, we diagnosed 683 tumours. Of those, 108 were malignant $(15.8 \%)$ and 48 were metastases (7.0\%) (Fig. 1). Therefore, $44.4 \%$ of all malignant parotid tumours $(n=108)$ were metastases, a higher proportion than primary epithelial parotid tumours at $37.0 \%(\mathrm{n}=40)$ and malignant lymphoma at $19.4 \%$ $(\mathrm{n}=21)$.

The number of parotid tumours rose steadily over the observation period: we diagnosed 121 parotid tumours in the first decade, 163 in the second, 183 in the third and 215 in the fourth decade (Table I and Fig. 1).

The incidence of parotid malignancies rose similarly over the entire observation period from 10 malignancies between 1975 and 1985 to 46 malignancies between 2005 and 2006 (Table I). This accounted for $8.3 \%$ of all parotid tumours between 1975 and 1986 (10 of 121), 13.5\% (22 of 163) between 1986 and 1995, 16.9\% (31 of 183)

Table I. Numbers of parotid tumours diagnosed between 1975 and 2015.

\begin{tabular}{lcccc}
$\begin{array}{l}\text { Number of } \\
\text { cases }\end{array}$ & $\mathbf{1 9 7 5 - 1 9 8 5}$ & $\mathbf{1 9 8 6 - 1 9 9 5}$ & $\mathbf{1 9 9 6 - 2 0 0 5}$ & $\mathbf{2 0 0 6 - 2 0 1 5}$ \\
All & 121 & 163 & 183 & 216 \\
Benign & 90 & 121 & 127 & 140 \\
Malignant & 10 & 21 & 31 & 46 \\
$\quad$ Primary & 9 & 12 & 19 & 20 \\
$\quad$ Metastasis & 1 & 9 & 12 & 26 \\
\hline
\end{tabular}




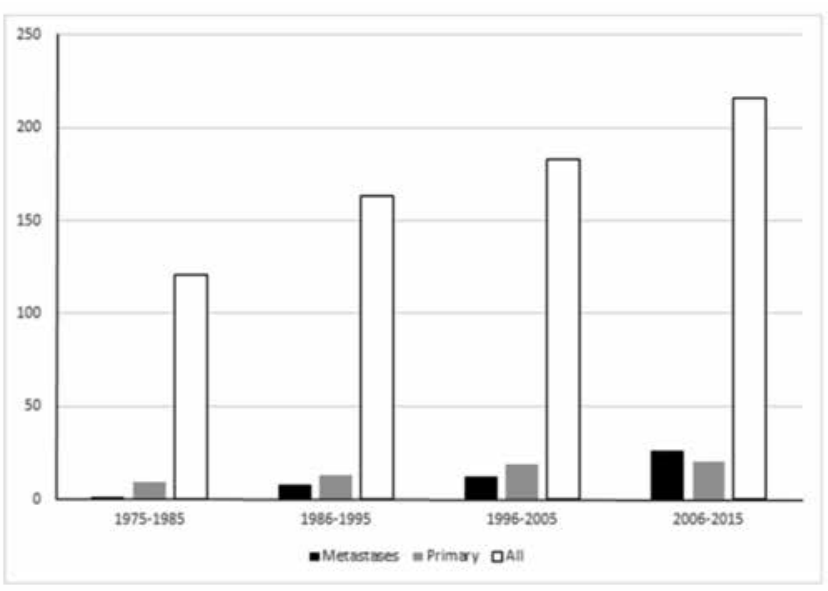

Fig. 1. Incidence of parotid tumours between 1975 and 2015.

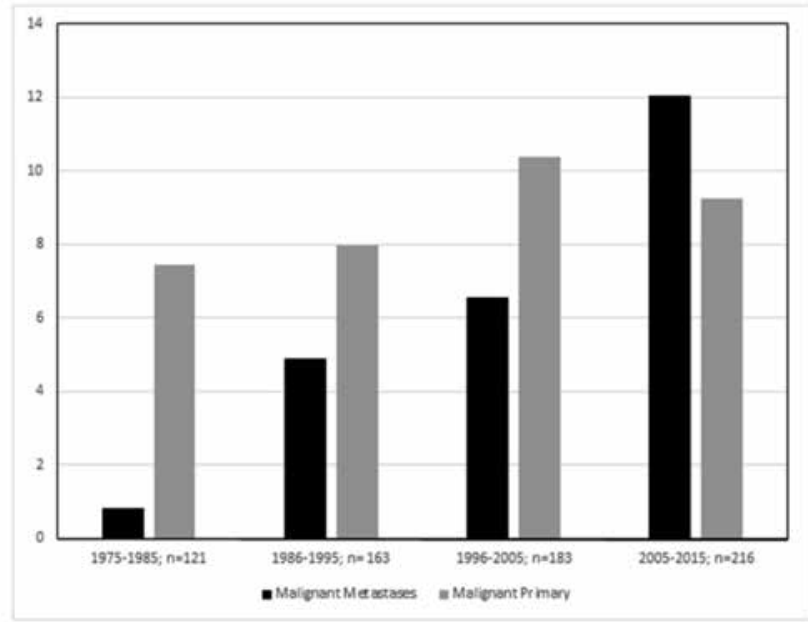

Fig. 2. Incidence of parotid metastases in percent of all parotid tumours diagnosed by decade between 1975 and 2015 .

between 1996 and 2005, and 21.3\% (46 of 216) of all parotid tumours between 2006 and 2015, demonstrating a nearly three-fold increase in the proportion of parotid malignancies amongst all parotid tumours (Fig. 2).

The proportion of parotid metastases rose out of proportion: in the first decade between 1975 and 1985, the proportion of metastases among malignant parotid tumours was $10 \%$ ( 1 of 10). This rose to $41 \%$ (9 of 22) in the second decade between 1986 and 1995 and 39\% (12 of 31) in the third decade between 1996 and 2005, and finally reached 57\% (26 of 26) in the final decade between 2006 and 2015.

Divided into two 20-year periods, it rose from $31.3 \%$ ( $\mathrm{n}=10$ of 32 malignant tumours) in period between 1975 to 1995 to $49.4 \%$ ( $n=38$ of 77 malignant tumours) in the period between 1995 to 2015 . Considering all tumours diagnosed during the decade, the number of parotid me- tastases rose from just under $1 \%$ ( $\mathrm{n}=1$ of 121 tumours) to $12 \%$ ( $\mathrm{n}=26$ of 215 tumours) (Fig. 2).

Metastatic parotid tumours affected 34 male patients (71\%) and 14 female patients (29\%) between the ages of 23 and 93 years, with a mean age of 68 years. Six patients were younger than 50 years old at the time of diagnosis.

The most commonly found metastatic tumours were those of a squamous cell carcinoma at $79 \%(\mathrm{n}=38)$ followed by malignant melanoma at $12.5 \%(n=6)$ of all metastatic lesions. Primary tumours were located above the clavicle in 42 of 48 cases (87\%), with 30 located in the facial skin or scalp, 9 in the oral cavity or pharynx and 3 in the ear canal. The remaining six primary tumours (13\%) were located below the clavicle and arose from primary tumours of the lung $(\mathrm{n}=3)$, kidney $(\mathrm{n}=1)$, distal oesophagus $(\mathrm{n}=1)$ and breast $(\mathrm{n}=1)$.

The period between diagnosis of the primary tumour and the parotid metastasis was 11 months on average (range 0-120 months).

Diagnosis was usually confirmed following histopathological evaluation of parotidectomy specimens. Patients received either a partial parotidectomy $(n=22)$, total parotidectomy $(\mathrm{n}=16)$, or a radical parotidectomy with facial nerve sacrifice ( $\mathrm{n}=1$, patient had pre-existing facial nerve palsy). Open biopsy alone was performed in 4 patients. In five patients we were unable to determine the exact type of parotidectomy.

Parotidectomy with concurrent excision of the skin tumour was performed in 33\% of cases (10 of 30), where staging of the primary tumour revealed a parotid lesion or due to size and histology of the skin lesion.

The excision of a carcinoma of the skin was performed in our patient group in $60 \%$ of cases (18 of 30) between 6 and 24 months prior to parotid surgery. These patients were referred to hospital for assessment and excision of a parotid lesion - the association between a previously operated skin tumour and the present parotid lesions was not recognised or unknown to the patient or referring or admitting clinician. This means that a significant number of these patients were operated on primary skin tumours without appropriate staging or that staging was performed, but patients were not referred or followed up appropriately.

We performed a contemporaneous neck dissection on 21 of 48 cases of metastatic parotid tumour (44\%). Adjuvant radiotherapy was carried out in 32 of 48 patients (67\%).

All patients were observed for at least seven years following parotid surgery, with the exception of those operated on after 2007, who continue to be under observation. Following diagnosis of a metastasis in the parotid gland, we observed tumour progression in 28 of 48 cases (58\%). This accounts for 5 of 6 cases of infraclavicular primary tumour (83\%), 6 of 9 cases of mucosal squamous cell carcinoma (67\%) and 17 of 30 cases of squamous cell carcinoma of the skin (57\%) during the observation period. 


\section{Discussion}

We observed a proportion of $44.4 \%$ metastases to the parotid gland in all parotid malignancies over a 40 -year period in our group of patients, but there has been an increase from $31 \%$ between 1975 and 1995 to $49 \%$ between 1995 and 2015. Even though our observations appear to diverge from other European series in that we have observed a higher number of metastatic tumours, it is noted that Bergersen and colleagues reported a similar proportion of parotid metastases nearly 30 years ago from a series of cases in Australia ${ }^{3}$. Similar observations were reported by others in North America more recently, where the proportion of parotid metastases was seen to increase ${ }^{515}$. When malignant parotid tumours were recorded in previous epidemiologic studies, a distinction between primary parotid malignancies and parotid metastases was not made ${ }^{1911}$.

Metastatic tumours of the parotid gland are more common in older age, the peak incidence in our patient group lies in the $7^{\text {th }}$ and $8^{\text {th }}$ decade. Younger patients are less commonly affected: only six of our 48 patients were younger than 50 years. On the other hand, we found a wide age range between 23 years and 93 years. Patients with metastatic parotid tumours were, in contrast to patients with malignant primary parotid tumours or parotid lymphoma, predominantly male (71\%). This may well be due to the higher incidence in skin squamous cell carcinoma and in squamous cell carcinoma of the head and neck in males ${ }^{7} 141617$.

In most cases, the primary tumour became manifest prior to the clinical manifestation of the parotid metastasis ${ }^{71416}$. The average period between the diagnosis of the primary tumour and the manifestation of parotid metastasis was 11 months in our group, but there was a wide variety between concurrent diagnosis and a 120 months interval. This also demonstrates the very diverse clinical course.

Squamous cell carcinomas are generally the most frequent carcinomas metastasising into the parotid gland ${ }^{13561416}$. In our patient group, squamous cell carcinomas were not just the most common metastatic tumours at $79 \%$, but they also represented the most frequent histological type of tumour at $33 \%$. The predominance of squamous cell carcinoma among parotid metastases has been described in multiple studies from Australia where there is high prevalence of cutaneous squamous cell carcinoma in a predominantly white population ${ }^{313}{ }^{14}$. Further evidence is provided by the largest population based study of the incidence of malignant parotid tumours to date, where the incidence of squamous cell carcinoma amounts to $20 \%$ in men and $15 \%$ in women, and, as in our group, represents the most common histological type ${ }^{1}$. Since primary squamous cell carcinoma of the parotid gland is rare, it is reasonable to conclude that a significant proportion of these squamous cell carcinomas are metastases ${ }^{18}{ }^{19}$. A diagnosis of primary parotid carcinoma should be a diagnosis of exclusion depending on histopathological findings, and metastasis should always be considered depending on histological type, and a primary tumour excluded.

Malignant melanoma is the second most common tumour type that metastasises into the parotid gland, and the proportion of primary cutaneous malignant melanoma metastasising into the parotid gland is higher than that of squamous cell carcinoma 672021 . Malignant melanomas very rarely arise in the parotid gland as a primary tumour and should generally be considered metastatic spread from a cutaneous melanoma, although mucosal melanoma and choroidal melanoma must also be considered as primary lesions ${ }^{2021}$.

As seen in our patient group, where $87 \%$ of primary tumours were located above the clavicle and within the lymphatic drainage area of the parotid lymph nodes, skin tumours of the face and scalp are the most common primary tumours metastasising into the parotid gland 2142122 . Direct infiltration from the buccal skin can also be observed, as seen in two of our cases of squamous cell carcinoma of the buccal skin.

Reports of parotid metastases of upper aerodigestive tract squamous cell carcinoma are rare compared to those of metastatic cutaneous carcinoma ${ }^{723}$. Considering all tumours diagnosed in the upper aerodigestive tract within the observation period, the incidence of parotid metastases in these tumours was less than $1 \%$ in our patient group and therefore of little relevance. Metastases of primary tumours located below the clavicle are reported to make up 10-20\% of all parotid metastases. As also seen in our patient group, where $13 \%$ were metastases of tumours below the clavicle, primary tumours are mostly located in the lung, breast and kidney, and more rarely seen in the gastrointestinal tract, prostate and infraclavicular skin ${ }^{24-30}$.

A distinction between primary glandular tumour and metastasis must be made in each case of parotid malignancy. This can be difficult considering the many types of primary tumours that have been described for parotid tumours, but is relevant for therapy and prognosis. When searching for a primary tumour, locations that should be considered first and foremost are the skin of face and scalp and the oral and pharyngeal mucosa, but also the lung, kidneys and breast ${ }^{3618}$.

Facial nerve palsies in parotid metastases are comparably rare and in our group of patients we observed two cases of facial nerve weakness ${ }^{25} 30$.

Parotid metastatic disease is associated with a high rate of local recurrence and tumour-associated mortality. A metastasis measuring $6 \mathrm{~cm}$ or more in diameter and facial nerve palsy are also factors that worsen prognosis. Resection of the parotid metastasis followed by adjuvant radiotherapy is considered the treatment of choice. In patients with parotid metastases of a cutaneous squamous cell carcinoma, neck dissection should always be performed, even in a clinically N0 neck ${ }^{4513}{ }^{31}$. The patients in our group were primarily cases in whom a 
parotid metastasis was diagnosed secondarily, i.e. 6-24 months following diagnosis of a primary tumour. Despite combined treatment and resection of recurrent parotid metastasis, the tumour recurred, either locally or systemically, in $58 \%$ of our patients with parotid metastases. We observed a much more favourable course in patients with a clinically N0 neck who underwent parotidectomy and neck dissection prior to a parotid metastasis being diagnosed compared to patients where a parotid metastasis was diagnosed secondarily, and even more so, that the neck and the salivary gland are included in the staging of primary malignant skin tumours. Similarly, Ebrahimi and colleagues reported that an interval of 9 months or less between detection of primary tumour and detection of a metastasis in squamous cell carcinoma of the scalp is an unfavourable prognostic factor ${ }^{17}$. Cutaneous cancers of the head and neck metastasising into the parotid gland may also be associated with increased expression of epidermal growth factor and are particularly aggressive and associated with poor outcome, requiring a different diagnostic regime and surgical and adjuvant management such as radiotherapy ${ }^{153132}$. Parotid metastases of infraclavicular primary tumours are often an expression of disseminated metastasis and carry a poor prognosis. In our cohort, only one of six patients with a parotid metastasis of a previously treated renal cell carcinoma (6 years after nephrectomy) is still alive and recurrence-free four years following parotidectomy. Parotidectomy is rarely considered curative in patients with infraclavicular primary tumours, but it is appropriate for symptom control and should therefore be offered to patients who are fit for surgery. Other than that, primary radio-chemotherapy should be considered depending on sensitivity of the primary tumour ${ }^{27} 33$. Literature following up parotid metastases of mucosal squamous cell carcinoma is very sparse, but prognosis tends to be poor ${ }^{23}$. In patients with malignant melanoma, parotid metastases are a unfavourable prognostic factor ${ }^{19-21}$.

\section{Conclusions}

Metastatic tumours of the parotid gland have an increasing significance in the spectrum of malignant parotid neoplasia. Parotid metastases are of high prognostic relevance and must be included when stratifying risk and planning treatment. As the majority of parotid metastases are metastases from squamous cell carcinoma of the skin of the head and neck, the majority of which are diagnosed well after treatment of the primary skin tumour, a structured aftercare regimen is required for patients with carcinoma of the skin of the head and neck and possibly for selected patients with infraclavicular primary tumours following primary treatment, which should involve a minimum of clinical otolaryngologi- cal examination and ultrasound examination of the neck and salivary glands. By diagnosing and treating such metastases early, tumour recurrence may be prevented but further research is required to assess the impact of early detection of parotid metastasis on survival and recurrence rates.

\section{References}

1 Boukheris H, Curtis RE, Land CE, et al. Incidence of carcinoma of the major salivary glands according to the WHO classification, 1992 to 2006: a population-based study in the United States. Cancer Epidemiol Biomarkers Prev 2009; 18:2899-906.

2 Bron LP, Traynor SJ, McNeil EB, et al. Primary and metastatic cancer of the parotid: comparison of clinical behavior in 232 cases. Laryngoscope 2003;113:1070-5.

3 Bergersen PJ, Kennedy PJ, Kneale KL. Metastatic tumours of the parotid region. Aust N Z J Surg 1987;57:23-6.

4 Chua MST, Veness MJ, Morgan G, et al. Parotid lymph-node metastases from cutaneous squamous-cell carcinomas: treatment outcome and prognostic factors following surgery and adjuvant radiotherapy. Australas Radiol 2002; 46:174-9.

5 Audet N, Palme CE, Gullane PJ, et al. Cutaneous metastatic squamous cell carcinoma to the parotid gland: analysis and outcome. Head Neck 2004;26:727-32.

6 Seifert G, Hennings K, Caselitz J. Metastatic tumors to the parotid and submandibular glands - analysis and differential diagnosis of 108 cases. Pathol Res Pract 1986;181:684-92.

7 Gnepp D. Metastatic disease to the major salivary glands. In: Tumours of the Salivary Glands. Philadelphia: WB Saunders; 1996. p. 421-5.

8. Eveson JW, Cawson RA. Salivary gland tumours. A review of 2410 cases with particular reference to histological types, site, age and sex distribution. J Pathol 1985;146:51-8.

9. Wahlberg P, Anderson H, Biörklund A, et al. Carcinoma of the parotid and submandibular glands - a study of survival in 2465 patients. Oral Oncol 2002;38:706-13.

10 Grant D, Bradley P. Epidemiology of malignant salivary gland neoplasms. In: Salivary Gland Disorders and Diseases.Diagnosis and Management; 2011. p. 247-51.

11 Jones A V, Craig GT, Speight PM, Franklin CD. The range and demographics of salivary gland tumours diagnosed in a UK population. Oral Oncol 2008;44:407-17.

12 Pomar Blanco P, Martín Villares C, San Román Carbajo J, et al. [Metastasis to the parotid gland]. Acta Otorrinolaringol Esp 2006;57:47-50.

13 Vauterin TJ, Veness MJ, Morgan GJ, et al. Patterns of lymph node spread of cutaneous squamous cell carcinoma of the head and neck. Head Neck 2006;28:785-91.

14 O'Brien CJ. The parotid gland as a metastatic basin for cutaneous cancer. Arch Otolaryngol Head Neck Surg 2005;131:551-5.

15 Hinerman RW, Indelicato DJ, Amdur RJ, et al. Cutaneous squamous cell carcinoma metastatic to parotid-area lymph nodes. Laryngoscope 2008;118:1989-96.

16 O'Hara J, Ferlito A, Takes RP, et al. Cutaneous squamous 
cell carcinoma of the head and neck metastasizing to the parotid gland - a review of current recommendations. Head Neck 2011;33:1789-95.

17 Ebrahimi A, Clark JR, Ahmadi N, et al. Prognostic significance of disease-free interval in head and neck cutaneous squamous cell carcinoma with nodal metastases. Head Neck 2013;35:1138-43.

18 Brauneis J, Laskawi R, Schröder M, Eilts M. [Squamous cell carcinoma in the area of the parotid gland. Metastasis or primary tumor?]. HNO 1990;38:292-4.

19 Gnepp D. Secondary Tumours. In: Tumours of the Salivary Glands. Philadelphia: WB Saunders; 1996. p. 403-10.

20 Wang BY, Lawson W, Robinson RA, et al. Malignant melanomas of the parotid: comparison of survival for patients with metastases from known vs unknown primary tumor sites. Arch Otolaryngol Head Neck Surg 1999;125:635-9.

21 Schwipper V, Schulze-Osthoff DR. [The parotid gland as a filtering station of metastatic head-neck melanoma. Retrospective study of 884 patients]. Mund Kiefer Gesichtschir 1998;2:242-9.

22 Teymoortash A. [Parotid gland as the main site of metastasis of the cutaneous squamous cell carcinoma of the head]. Laryngorhinootologie 2007;86:699-704.

23 Pisani P, Krengli M, Ramponi A, et al. Metastases to parotid gland from cancers of the upper airway and digestive tract. Br J Oral Maxillofac Surg 1998;36:54-7.

24 Cantera JM, Hernandez A V. Bilateral parotid gland metastasis as the initial presentation of a small cell lung carcinoma. J Oral Maxillofac Surg 1989; 47:1199-201.
25 Shalowitz JI, Cassidy C, Anders CB. Parotid metastasis of small cell carcinoma of the lung causing facial nerve paralysis. J Oral Maxillofac Surg 1988;46:404-6.

26 Mrena R, Leivo I, Passador-Santos F, et al. Histopathological findings in parotid gland metastases from renal cell carcinoma. Eur Arch Otorhinolaryngol 2008;265:1005-9.

27 Bissett D, Bessell EM, Bradley PJ, et al. Parotid metastases from carcinoma of the breast. Clin Radiol 1989;40:309-10.

28 Laforga JB, Gasent JM. Mammary invasive duct carcinoma metastatic to parotid gland: report of a case diagnosed by fine-needle aspiration. Diagn Cytopathol 2009;37:154-8.

29 Park YW, Hlivko TJ. Parotid gland metastasis from renal cell carcinoma. Laryngoscope 2002;112:453-6.

30 Kundu S, Eynon-Lewis NJ, Radcliffe GJ. Extensive metastatic renal cell carcinoma presenting as facial nerve palsy. J Laryngol Otol 2001;115:488-90.

31 Bumpous J. Metastatic cutaneous squamous cell carcinoma to the parotid and cervical lymph nodes: treatment and outcomes. Curr Opin Otolaryngol Head Neck Surg 2009;17:122-5.

32 Shao A, Wong DKC, McIvor NP, et al. Parotid metastatic disease from cutaneous squamous cell carcinoma: prognostic role of facial nerve sacrifice, lateral temporal bone resection, immune status and P-stage. Head Neck 2014;36:545-50.

33 Deeb R, Zhang Z, Kini S, et al. Metastatic renal cell carcinoma to the parotid gland presenting 19 years after nephrectomy: case report and review of literature. Laryngoscope 2010;120 Suppl:S128.

Received: February 12, 2016 - Accepted: September 21, 2016

Address for correspondence: Achim Franzen, Campus Ruppiner Kliniken, Fehrbelliner Strasse 38, 16816 Neuruppin, Germany. Tel. +49 3391 393601. Fax +49 3391 393609. E-mail: a.franzen@ ruppiner-kliniken.de 